\title{
Three new ichneumonid species of the genus Lymeon Förster, 1869 (Hymenoptera: Ichneumonidae: Cryptinae) from Mexico
}

\section{Три новых вида наездников-ихневмонид рода Lymeon Förster, 1869 (Hymenoptera: Ichneumonidae: Cryptinae) из Мексики}

\author{
D.R. Kasparyan \\ A.P. Каспарян
}

\begin{abstract}
Zoological Institute, Russian Academy of Sciences, St. Petersburg, Russia. E-mail: kasparyan@yandex.ru Зоологический институт Российской Академии наук, Санкт-Петербург, Россия.
\end{abstract}

KEY WORDS: Cryptini, Lymeon, new species, key, Veracruz, Mexico, Neotropic Region, North America.

КЛЮЧЕВЫЕ СЛОВА: Cryptini, Lymeon, новые виды, определительный ключ, Мексика, Неотропика, Северная Америка.

ABSTRACT. Three new species of the subfamily Cryptinae (Hymenoptera: Ichneumonidae) of the genus Lymeon Förster, 1869 are described from the State of Veracruz, Mexico: L. caudator sp.n., L. scitula sp.n. and L. xalapensis sp.n. A key to 11 North and Central American species of Lymeon with reddish brown metasoma is provided.

РЕЗЮМЕ. Три новых вида подсемейства Cryptinae (Hymenoptera: Ichneumonidae) описаны в роде Lymeon Förster, 1869 из штата Веракрус, Мексика: L. caudator sp.n., L. scitula sp.n. и L. xalapensis sp.n. Дан определительный ключ 11 северо- и центральноамериканских видов Lymeon с коричневатокрасной метасомой.

\section{Introduction}

The genus Lymeon Förster, 1869 belongs to the Neotropical subtribe Lymeonina of the tribe Cryptini (Ichneumonidae: Cryptinae). It is one of the largest genera of Cryptini that comprises about 90 species occurring almost exclusively in the Neotropical region [Yu et al., 2016], with only four species known from Nearctic region [Townes, Townes, 1962]. Species of the genus usually attack small cocoons of various insects and egg cocoons of spiders [Townes, 1970]. North and Central American species of Lymeon were reviewed and keyed in a series of my earlier papers [Kasparyan, 2004, 2013, 2017; Kasparyan, Ruíz-Cancino, 2004, 2008a, b].

About 32 species were recorded from Mexico hitherto. The aim of this work is to describe three new species of Lymeon from the State of Veracruz, Mexico, and to provide a key to 11 North American species of the genus with reddish brown metasoma.

\section{Material and Methods}

This work is based on the review of species of the genus Lymeon occurring in Central America and Mexico [Kasparyan, Ruíz-Cancino, 2004] and monographs on the North American [Townes, Townes, 1962] and Mexican [Kasparyan, Ruíz-Cancino, 2008a] Cryptini. Types of Lymeon species described by P. Cameron, E.T. Cresson, R.A. Cushman, H.K and M. Townes were examined in the Academy of Natural Sciences of Philadelphia, Philadelphia, USA; U.S. National Museum of Natural History, Washington, USA; Townes \& Dasch collections (former American Entomological Institute), recently moved to the Utah State University, Logan, Utah, USA; and the Natural History Museum, London, UK.

Three new species of Lymeon were discovered from the ichneumonid material recently collected by M. López-Ortega (Instituto de Biotecnología y Ecología Aplicada, Universidad Veracruzana, Xalapa) from the State of Veracruz, Mexico. Type material (including all holotypes) is deposited in the Instituto de Biología, Universidad Nacional Autónoma de México, DF, Mexico (UNAM) except for one paratype preserved in the Zoological Institute of the Russian Academy of Sciences, St. Petersburg, Russia [ZIN].

Morphological terminology mainly follows that of Townes [1970]. Taxonomy follows the catalogue Taxapad [Yu et al., 2016]. Layer photographs were taken in ZIN with a Canon EOS 70D digital camera attached to an Olympus SZX10 stereomicroscope, and partially

How to cite this article: Kasparyan D.R. 2021. Three new ichneumonid species of the genus Lymeon Förster, 1869 (Hymenoptera: Ichneumonidae: Cryptinae) from Mexico // Russian Entomol. J. Vol.30. No.1. P.84-92. doi: 10.15298/rusentj.30.1.10 
focused images were assembled with Helicon Focus 6 Pro software.

\section{Descriptions of new species}

Family Ichneumonidae

Subfamily Cryptinae

Tribe Cryptini

Subtribe Lymeonina

Genus Lymeon Förster, 1869

Type species: Lymeon annulicorne Ashmead, 1894 (= L. orbus Say, 1835).

\section{Lymeon caudator Kasparyan, sp.n.}

Figs 1-3.

MATERIAL EXAMINED. Holotype: ㅇ, Mexico, Veracruz, Xalapa, USBI, Malaise trap, May 2017 (M. López-Ortega) (UNAM).

COMPARISON. Lymeon caudator sp.n. differs from its congeners by its unusually long ovipositor (ovipositor sheath 1.33 times as long as hind tibia) with weak nodus and a long postnodal part of the upper valve (in the latter feature it converges with the genus Debilos Townes, 1966 see Comparative notes below). In its colouration (Figs 1-2) the new species differs from all North American species of Lymeon with red propodeum and black with white markings metasoma by its entirely black mesoscutum. In colour pattern, $L$. caudator sp.n. is very similar to L. rufotibialis Kasparyan et Ruíz-Cancino, 2004; the latter species also has a rather long ovipositor, i.e. ovipositor sheath as long as hind tibia ( $v s$ 0.50.8 times in most other congeners), weak nodus, a long postnodal part of the upper valve of ovipositor, and reduced brachiella; but in L. rufotibialis the ovipositor is shorter, mesoscutum with two whitish stripes, hind tibia uniformly reddish and tergite 8 white-marked.

DESCRIPTION. Female (holotype). Fore wing length $7.6 \mathrm{~mm}$.

Antenna with 24 flagellomeres; flagellomeres 1 and 2 subequal in length, their combined length about 1.65 times as long as maximum diameter of eye; flagellomeres 4-9 distinctly compressed and widened, 1.4-1.6 times as wide as flagellomeres 1 and 2 at apex; flagellomere 8 on inner side near its apical margin with a bunch of $6-8$ short setae.

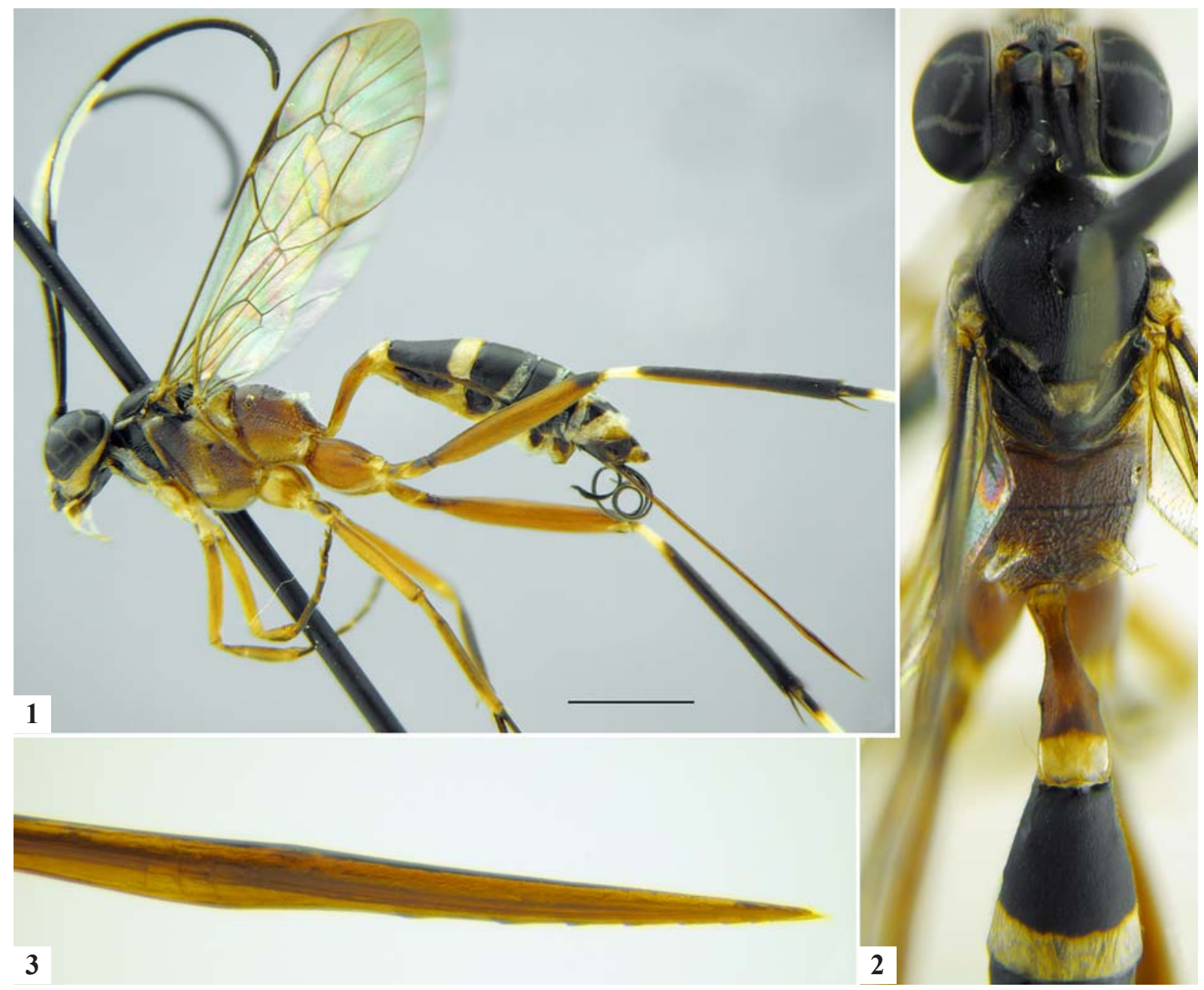

Figs 1-3. Lymeon caudatus sp.n., female, holotype. 1 - habitus, lateral view; 2 - head, mesosoma and base of metasoma, dorsal view; 3 - apex of ovipositor, lateral view. Scale bar in Fig. $1-2.0 \mathrm{~mm}$.

Рис. 1-3. Lymeon caudatus sp.n., голотип (самка): 1 общий вид, сбоку; 2 голова, мезосома и основание метасомы, сверху; 3 вершина яйцеклада, сбоку. Масштабная линейка к рис. $1-2.0$ мм. 
Flagellomeres 10-21 subcylindrical, 1.4-1.8 times as long as wide; the apical one about 2.1 times as long as wide at base. Face mat, laterally evenly finely granulate with fine punctures, and medially scabrous with fine rugosity, covered with rather dense and moderately long setae. Clypeus polished, strongly convex in profile, with scarce large punctures, setae thin and long; clypeus with transverse ridge which is highest in lower 0.35 of clypeus; lower margin of clypeus sharp, truncate, slightly impressed and darkened. Frons mat, finely granulate laterally, with coarse rugosity centrally, and with thin median longitudinal carina, the setae are rather short and moderately dense.

Vertex and temples very finely and shallowly granulate, with fine and moderately sparse punctures. Head very strongly narrowed behind eyes. Temple broadened to mandible, in profile its maximum length about 2.5 times more than its minimum length at level of upper 0.25 of eye. Occipital carina weakly sinuate before its connection with hypostomal carina; oral carina slightly higher than occipital carina and about 0.6 times as long as basal mandibular width. Malar space half as long as basal mandibular width. Mandible rather narrow at apex, its upper tooth hardly longer than the lower tooth.

Epomia strong. Notauli sharp in anterior 0.3 of mesoscutum. Mesoscutum mat, very finely granulose and covered with dense fine punctures and short setae; central 0.4 of mesoscutum in posterior 0.6 with coarse and dense longitudinal rugae. Prescutellar groove with about 8 short and strong transverse rugae. Scutellum polished with irregular rather dense punctures. Mesopleuron with dense and strong longitudinal rugae. Speculum convex, smooth, with moderately large dense punctures. Mesosternum densely and finely granulose-punctate, with setae moderately short and dense. Metapleuron with very coarse and dense irregular rugae, juxtacoxal carinae absent; upper division of metapleuron (beyond the upper half of epimeron) almost smooth and covered with dense and moderately large punctures and dense, fine and long setae. Postscutellum in basal half with lateral carinae and with a pair of basal deep pits. Groove between propodeum and metanotum just behind postscutellum moderately wide and deep; its anterior slope on hind edge of metanotum without small tooth laterad of postscutellum. Propodeum with coarse irregular rugosity; basal transverse carina complete; apical transverse carina absent and represented by a pair of apophyses (Figs 1-2); apophyses conical, 1.2 as long as their basal diameter.

Fore wing with areolet pentagonal, almost rectangular, moderately large, 1.1 times as long as second recurrent vein above bulla (Fig. 1). Nervulus slightly antefurcal; postnervulus intercepted at anterior 0.3 . Nervellus intercepted at posterior 0.35 ; brachiella very short, 0.15 times as long as distance to wing margin. Hind femur 6.3 times as long as wide. Proportions of length of hind tarsomeres $1-5: 7.5: 2.8: 1.6$ : $0.7: 2.0$.

First metasomal segment slender, 3.2 times as long as wide at posterior margin and 8.6 times as long as minimum width of petiole; first tergite evenly covered with dense fine granulation except for extreme apex and basal half of petiole which are almost polished, its dorsolateral and ventrolateral carinae absent. Second tergite 1.3 times as long as wide at posterior margin, and wider posteriorly than anteriorly; its surface mat, very evenly and finely granulate with very scarce short setae; sculpture of following tergites similar to that of tergite 2 but finer and shallower on each subsequent tergite, with punctures becoming larger and pubescence longer. Ovipositor sheath 1.35 times as long as hind tibia (Fig. 1). Tip of dorsal valve of ovipositor with nodus weakly designated, behind nodus rather slender and very long (Fig. 3), 1.4 times as long as hind tarsomere 2 and 8.0 times as long as height of ovipositor at level of nodus.

Antenna black with flagellomeres 4-9 white, black ventrally. Head, prothorax, mesonotum and metasoma, hind tibia and tarsus marked with whitish and black; remaining mesosoma, first segment of metasoma and legs reddish with a few whitish markings (Figs 1-2). Head whitish with central wide black band extending from clypeal suture to occipital carina; eye orbits completely whitish, not interrupted by black; temples narrowly black along occipital carina; clypeus on lower margin and laterally, mandibles (except for large white spot on right mandible), small spot on malar space and entire occiput all black; palpi whitish.

Prothorax black with white markings on anterior and posterior edges of propleuron, front and dorsolateral margins of pronotum completely white. Mesoscutum completely black with obscure whitish marking on its lateral carina behind axillary tongue, prescutellar carinae black; spiracular sclerite before tegula blackish, tegula whitish anteriorly and posteriorly with large median black spot, subalar prominence below tegula blackish; scutellum whitish dorsally, black laterally and at apex; metanotum blackish brown with postscutellum blackish (Figs 1-2). Mesopleuron, mesosternum, metapleuron and propodeum reddish brown with yellowish, whitish and brownish markings, and apophyses of propodeum white (see Fig. 1). Fore wing hyaline with apical 0.15 weakly infuscate; distal part of brachial cell slightly infuscate (Fig. 1). Fore and mid coxae reddish with brown marks, white dorsally; trochanters white with brown dorsal stripe; trochantelli, femora and tibiae yellowish brown; tarsi dark brown. Hind coxa, femur and trochanters reddish except for blackish posterior 0.12 of femur and brown and whitish markings on trochanters; hind tibia black with subbasal 0.15 white (Fig. 1 ); hind tarsus predominantly white, basal 0.25 of basitarsus and entire tarsomere 5 black.

Metasomal tergite 1 reddish, tergites 2-8 black; tergites 1-7 with wide posterior white bands (Fig. 1), these bands on tergites 3, 5 and 6 dorsally interrupted; sternites $2-5$ yellowish with large blackish lateral spot; sternite 6 light brown with strong basal desclerotization.

Male. Unknown.

COMPARATIVE NOTES. Lymeon caudator sp.n. belongs to the subtribe Lymeonina, but in the habitus and characteristic shape of the ovipositor it resembles the Neotropical genus Debilos of the subtribe Goryphina (especially D. prionilix Scherrer, 2012). In the revision of Debilos [Scherrer, Aguiar, 2012], authors noted that the similarity of the Debilos in "the body size and general shape, combined with $\mathrm{T}$ [ergite] 1 without lateral triangular tooth or flange at base" can make the species of this genus resemble the species of Lymeon. They proposed following characters that separated Lymeon from Debilos. The Lymeon has mandible more stout, lower tooth 0.6-0.8 times as long as upper tooth ( $v S$ ventral tooth about half length of dorsal tooth in Debilos); nervulus antefurcal; and ventral valve of ovipositor with a long series of teeth ( $v s$ nervulus interstitial or postfurcal in Debilos and teeth of lower valve inconspicuous and restricted to its extreme tip). Lymeon caudator sp. $\mathbf{n}$. shares all these features of Lymeon. The new species also differs from Debilos in its predominantly whitish colouration of head, whereas in all 30 known species of Debilos the head is completely black, except for occasionally white clypeus or mandibles.

ETYMOLOGY. The species name is a noun from the Latin "caudatus" (caudate, tailed) referring to the long ovipositor. 


\section{Lymeon scitula Kasparyan, sp.n.}

Figs 4-8.

MATERIAL EXAMINED. Holotype: + , Mexico, Veracruz, Municipio Teocelo, Tejerias, Malaise trap, November 2016 (M. López-Ortega) (UNAM).

COMPARISION. Lymeon scitula sp.n. is similar to $L$. xalapensis sp.n. in general habitus, colouration (pale reddish metasoma and legs, mesosoma predominantly black with white markings), and lack of the apical transverse carina which in both species is represented by a pair of low and wide obtuse apophyses (Figs 7, 12). Lymeon scitula may easily be distinguished from L. xalapensis by black speculum and mesosternum, completely black mesoscutum (Fig. 6), longer petiole (compare Figs 7 and 12) and tergites 7 and 8 with white dorsal


8

Figs 4-8. Lymeon scitula sp.n., female, holotype. 4- habitus, lateral view; 5 - head, frontal view; 6 - head and anterior part of thorax, dorso-lateral view; 7 - propodeum, hind coxae and first tergite of metasoma, dorsal view; 8 - apex of ovipositor, lateral view. Scale bar in Fig. $4-2.0 \mathrm{~mm}$.

Рис. 4-8. Lymeon scitula sp.n., голотип (самка): 4 общий вид, сбоку; 5 голова, спереди; 6 - голова и передняя часть груди, сбоку и сверху; 7 - проподеум, задние тазики и тергит 1 метасомы, сверху; 8 - вершина яйцеклада, сбоку. Масштабная линейка к рис. $4-2.0$ мм. 
spot (compare Figs 4 and 9). Lymeon scitula is also similar to L. maculipennis Kasparyan, 2017 and L. yanegai Kasparyan, 2004 as all these species possess the apical transverse carina reduced, metasoma reddish, and clypeus with a pair of small median teeth on its lower margin; the two latter species can easily be distinguished from all other known species by entirely pale reddish body with head mainly yellow. The differences from these and other North American species with reddish metasoma are given below in the key.

DESCRIPTION. Female (holotype). Fore wing length 4.5 $\mathrm{mm}$. Antenna with 22 flagellomeres; flagellomeres 1 and 2 almost subequal and combined about 1.52 times as long as maximum diameter of eye; flagellomeres 4-9 weakly compressed and broadened, 1.3 as wide as flagellomeres 1 and 2 . Flagellomeres 10-21 are subcylindrical, about 1.33 times as long as wide; the apical one 2.5 times as long as wide, it is of same diameter as previous ones. Face mat, evenly finely granulate with sparse inconspicuous setiferous punctures, the setae very fine and moderately long. Clypeus rather strongly and evenly convex in profile, smooth with scarce punctures; its lower margin sharp and with two small median teeth. Frons mat, with weak median longitudinal carina, evenly granulate with dense and moderately fine punctures, its lower half above antennal sockets with a pair of superficial concavities; ocellar area rugose-punctate. Head very strongly narrowed behind eyes (dorsal view). Temple broadened to mandibles, in profile their maximum length about 2 times more than its minimum length at level of dorsal 0.25 of eye. Occipital carina weakly sinuate before its connection with hypostomal carina; oral carina as high as occipital carina and about 0.5 times as long as basal width of mandible. Malar space 0.8 times as long as basal width of mandible. Mandible rather narrow at apex, its upper tooth 1.3 times as long as lower tooth.

Epomia distinct, rather short. Notauli distinct. Mesoscutum mat, very finely granulose, covered with moderately dense short setae. Prescutellar groove without transverse rugae. Scutellum polished with scarce punctures. Mesopleuron mat, covered with dense longitudinal rugosity and with inconspicuous rather sparse setiferous punctures, the setae moderately short; rugae rather coarse in upper half of mesopleuron and finer in lower half; rugae absent below sternaulus. Speculum large and polished. Mesosternum finely granulate with very fine transverse striation, covered with fine and sparse setiferous punctures. Metapleuron finely granulate, in lower 0.4 with thin oblique fine striae; its upper division (just behind upper part of epimeron) smooth with moderately sparse punctures. Postscutellum in basal 0.7 with lateral carinae and with a deep pit in basal corner. Groove between propodeum and metanotum just behind postscutellum narrow and deep. Propodeum with the basal transverse carina thin and complete; the apical transverse carina absent and represented by a pair of large apophyses; apophyses conical, wide, obtuse, 0.5 times as long as wide at base (Fig. 7). Propodeum before the basal transverse carina evenly finely granulate, beyond this carina to apophyses with fine granulation with fine transverse rugosity; beyond apophyses level with coarse transverse rugae and with coarse reticulation between apophyses; basal area very narrow posteriorly and broad anteriorly. Propodeum behind basal transverse carina entirely scabrous (in irregular small rugosity); apical transverse carina absent.

Areolet small, about half as long as 2 nd recurrent vein above the bulla (Fig. 4). Nervulus about interstitial (shortly antefurcal); postnervulus intercepted at anterior 0.33. Nervellus intercepted at posterior 0.36 ; brachiella present, reaching about 0.5 of distance to wing margin. Hind femur 5.7 times as long as wide. Proportions of length of hind tarsomeres 1-5: $7.2: 3.1: 2.2: 0.8: 1.8$.

Metasomal segment 1 slender, 2.9 times as long as wide at posterior margin and 7 times as long as minimum width of petiole; first tergite evenly covered with dense granulation except for its extreme base and apex, dorsolateral and ventrolateral carinae absent. Tergite 2 at posterior margin 2.2 times as wide as at anterior margin and 1.15 times as long as maximum width; its surface mat, very evenly and finely granulate with very scarce short setae; sculpture of following tergites rather similar to that of tergite 2 but finer and smoother on each subsequent tergite and becomes hardly discernible on tergite 7. Tip of dorsal valve of ovipositor behind the nodus rather slender, as long as segment 2 of hind tarsus and about 5.0 times as long as height of ovipositor on nodus (Fig. 8). Ovipositor 1.3 times as long as hind tibia, ovipositor sheath about as long as tibia.

Antenna black, flagellomeres 4-10 white dorsally, blackish ventrally; scape and pedicel blackish, scape whitish ventrally. Head with face, clypeus, mouthparts and orbits completely whitish; black are broad median longitudinal band from antennal sockets to occipital carina, hind half of temple and vertex, and entire occiput. Mesosoma black with white markings and reddish in posterior third of propodeum beyond apophyses (Figs 4, 6-7); propleuron white, mesoscutum and mesosternum entirely black; scutellum whitish with hind margin black, apophyses of propodeum white. Fore wing weakly infuscate in apical 0.2 , on brachial cell and on posterior half of discomedian cell. Fore and mid coxae and their trochanters white; their trochantelli light brownish with white marking on anterior side. Fore and mid femora and tibiae light brownish, tarsi brownish. Hind coxa, trochantellus and femur completely reddish, hind trochanter blackish with reddish dorsal marking; hind tibia light brownish with blackish extreme base and obscure subbasal pale marking; hind spurs brown. Hind tarsus white with basal $0.25-0.3$ of basitarsus and entire tarsomere 5 blackish. Metasomal tergites pale reddish with apical 0.15 of tergite 1 whitish, and tergites 7 and 8 with white apical spot (Fig. 4), sternites 2-4 predominantly dark brown, sternites 5 and 6 light brown.

Male. Unknown.

ETYMOLOGY. The name "scitula" emphasizes the similarity of the new species in habitus and colouration with the abundant Mexican species Diapetimorpha scitula (Cresson, 1873).

REMARKS. Diapetimorpha scitula (Cresson, 1873) may be distinguished from L. scitula sp.n. in having the first metasomal tergite with lateral tooth at base (such tooth is typical for Diapetimorpha and many other genera of Goryphina), in having mesoscutum with two median yellowish stripes, white spot covering apophyses larger and extending from basal transverse carina to hind edge of propodeum, and the apophyses longer and depressed.

\section{Lymeon xalapensis Kasparyan, sp.n.} Figs 9-13.

MATERIAL EXAMINED. Holotype: + , Mexico, Veracruz, Xalapa, USBI, Malaise Trap, January-February 2018 (M. LópezOrtega) (UNAM). Paratypes, $3+$, same locality and collector as holotype: $1+$ February 2017 (UNAM), $1+$ January-February 2018 (UNAM), 1 ㅇ March 2018 (ZIN).

COMPARISION. Lymeon xalapensis sp.n. is similar to L. scitula sp.n. as both have broad, low and obtuse apophyses on the propodeum, whitish and black colouration of head and mesosoma, and pale reddish brown metasoma and hind legs. Lymeon xalapensis can easily be distinguished from L. scitu- 


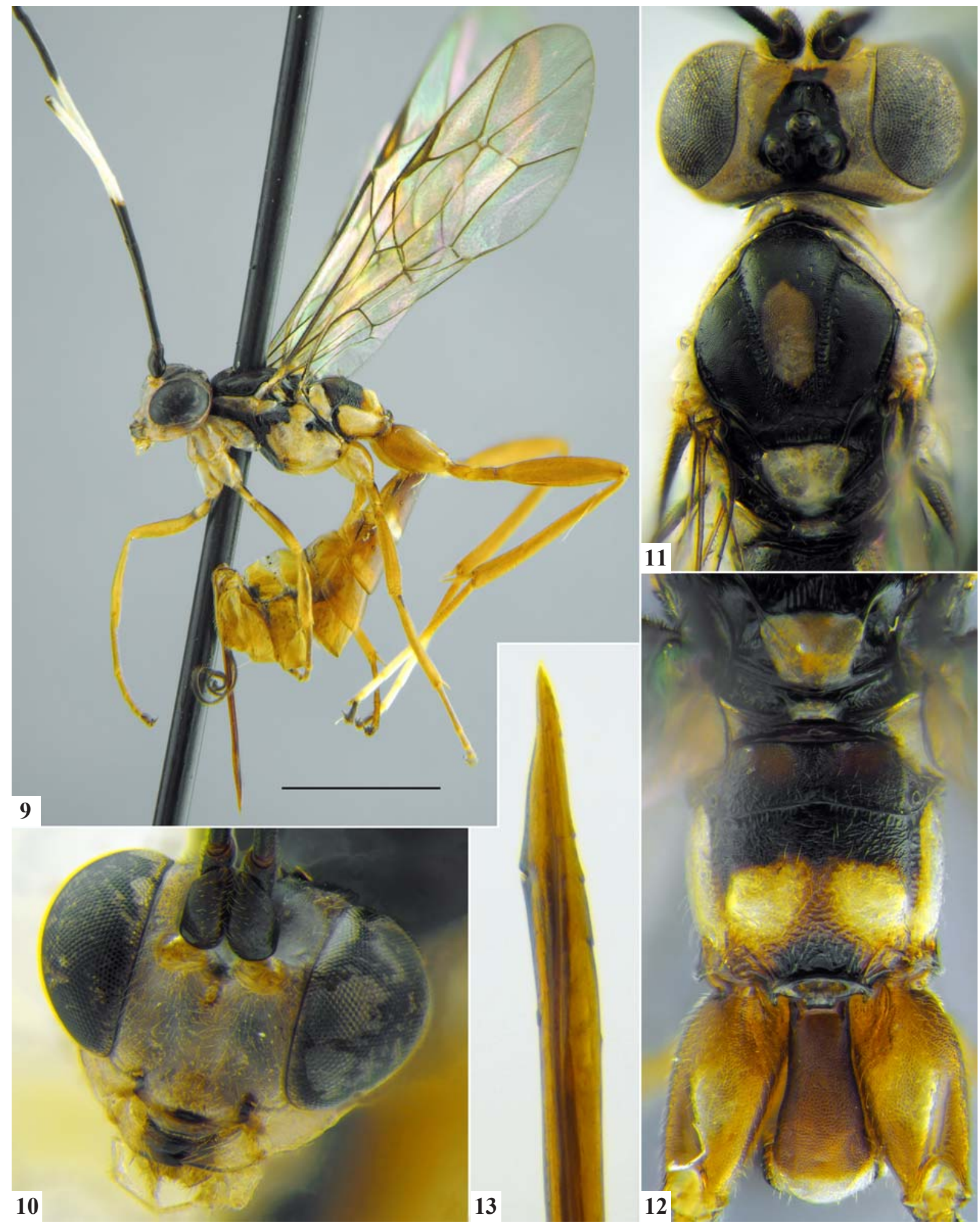

Figs 9-13. Lymeon xalapensis sp.n., female: 9- habitus, lateral view; 10 - head, frontal view; 11 - head and anterior part of mesosoma, dorsal view; 12 - hind part of mesosoma, hind coxae and first tergite of metasoma, dorsal view; 13 - apex of ovipositor, lateral view. Scale bar in Fig. $9-2.0 \mathrm{~mm}$.

Рис. 9-13. Lymeon xalapensis sp.n., female: 9 - общий вид, сбоку; 10 - голова, спереди; 11 - голова и передняя часть мезосомы, сверху; 12 - задняя часть мезосомы, задние тазики и тергит 1 метасомы, сверху; 13 - вершина яйцеклада, сбоку. Масштабная линейка к рис. $9-2.0$ мм. 
la in having speculum and mesosternum whitish (Fig. 9), mesoscutum with a large oval white spot centrally (Fig. 11), almost polished frons, granulate clypeus and black ventrally scape of antenna (Fig. 10) (see also the key below, couplet 4).

Description. Female (holotype). Fore wing length 5.9 $\mathrm{mm}$. Antenna with 24 flagellomeres; flagellomeres 1 and 2 almost subequal and combined about 1.65 times as long as maximum diameter of eye; flagellomeres 4-9 subcylindrical and weakly widened, 1.2 as wide as flagellomeres 1 and 2 . Flagellomeres 10-23 are subcylindrical, about 1.5-1.7 times as long as wide; the apical one about 2.5 times as long as wide, 0.9 times as wide as previous ones. Face and clypeus mat, evenly finely granulate, the setae sparse and moderately long. Clypeus rather strongly convex in profile, with scarce punctures; its transverse ridge with the maximum height just below the middle, with some anteriorly directed strong setae; lower margin of clypeus sharp truncate, centrally slightly impressed and darkened (Fig. 10). Frons shining, with very smoothened fine granulation, with thin median longitudinal groove, punctures fine and moderately sparse, setae moderately short; its lower half above antennal sockets with a pair of large and almost polished superficial concavities. The vertex and temples polished with fine sparse punctures. Head very strongly narrowed behind eyes (dorsal view). Temple broadened to mandibles, in profile their maximum length about 2 times more than its minimum length at level of dorsal 0.25 of eye. Occipital carina weakly sinuate before its connection with hypostomal carina; oral carina slightly higher than occipital carina and about 0.5 times as long as basal width of mandible. Malar space 0.75 times as long as basal width of mandible. Mandible rather narrow at apex, its upper tooth hardly longer than the lower tooth.

Epomia absent. Notauli deep and long. Mesoscutum mat, very finely granulose, covered with scarce moderately large punctures and scarce short setae. Prescutellar groove with about 8 short transverse rugae. Scutellum polished with scarce punctures. Mesopleuron shining, covering with scarce fine punctures, without rugosity, polished in upper half, and smooth with the traces of granulation in lower half. Speculum is large and polished. Mesosternum smooth with moderately large punctures with rather short setae. Metapleuron shining, finely and evenly granulate, without rugosity, and with scarce moderately large punctures with rather long setae; its upper division (just behind upper part of epimeron) almost smooth with rather short fine setae. Postscutellum in basal 0.7 with lateral carinae and with a pair of deep pits at base. Groove between propodeum and metanotum just behind postscutellum narrow and deep; its anterior slope without small tooth laterad of postscutellum at its hind edge. Propodeum with the basal transverse carina thin and complete; the apical transverse carina absent and represented by a pair of large obtuse apophyses (Fig. 12); apophyses conical, low, 0.5 as high as their basal diameter; propodeum finely granulate with fine scabrosity, between apophyses and near hind margin with longitudinal rugosity.

Areolet small, about half as long as 2 nd recurrent vein above the bulla. Nervulus shortly antefurcal; postnervulus intercepted at anterior 0.32 (Fig. 9). Nervellus intercepted at posterior 0.36 ; brachiella present, reaching about 0.5 of distance to wing margin. Hind femur 5.0 times as long as wide. Proportions of length of hind tarsomeres 1-5: $7.7: 3.6$ $: 2.2: 0.8: 1.8$
Metasomal segment 1 slender, 4 times as long as minimum width of petiole and 2 times as long as wide at posterior margin; first tergite evenly covered with dense granulation except for its extreme base and apex, dorsolateral and ventrolateral carinae absent. Tergite 2 at posterior margin 1.0 times as wide as long, and 2.5 times as wide as its width at anterior margin; its surface mat, very evenly and finely granulate with very scarce short setae; sculpture of following tergites rather similar to that of tergite 2 but finer and smoother on each subsequent tergite and becomes hardly discernible on tergites 6-8. Tip of dorsal valve of ovipositor behind the nodus rather slender, 1.4 times as long as segment 2 of hind tarsus and 3.6 times as long as height of ovipositor on nodus; apical 0.33 of upper valve beyond the nodus distinctly depressed (Fig. 13). Ovipositor 1.25 times as long as hind tibia, ovipositor sheath 0.8 as long as tibia.

Antenna black with flagellomeres 4-9 entirely white. Head and mesosoma with yellowish white and black markings, metasoma pale reddish brown marked with whitish (Figs 9, 12). Head whitish except for dark brown mandibular teeth, a small central and two lateral markings on the lower margin of clypeus (Fig.10), and a narrow black median band going from gap between antennal sockets to occipital carina; occiput black except for postgenae. Mesosoma black with white pattern and small reddish markings on propodeum (Figs 9, 11-12); propleuron white. Mesoscutum black with a white central oval large spot covering at least 0.5 of mesoscutum length; scutellum whitish dorsally with hind margin black (Fig. 11). Mesopleuron and mesosternum yellowish white with front margin, ventral part of prepectus, wide band under subtegular ridge, short line from mesopleural pit to epimeron and lower half of epimeron black (Fig. 9). Postscutellum white. Metapleuron whitish with sutures black. Propodeum black with two large white spots on apophyses, and with reddish gap between apophyses (Fig. 12). Fore wing translucent, without infuscation. Fore and mid coxae completely white; their trochanters light brown, white anteriorly; their trochantelli light brownish. Fore and mid femora, tibiae and tarsi pale brownish, with fifth tarsomere brown. Hind legs light brownish red with a large dorso-posterior white spot on coxa; apex of basitarsus, fourth tarsomere except blackish apex, and tarsomere 2 and 3 entirely white; fifth tarsomere blackish. Metasomal tergites pale reddish brown with apical 0.15 of tergites 1 and 2 white; extreme hind edge of tergite 2 light reddish brown, hind corner of tergite 3 with white small marking; sternites pale yellowish brown, marked with dark brown at base of sternites 2 and 3 .

Male. Unknown.

ETYMOLOGY. The species name refers to the type locality Xalapa.

Key to North and Central American species of Lymeon with reddish metasoma* (except L. caudator sp.n.)

1. Ovipositor unusually long, sheath 1.35 times as long as hind tibia. Metasomal tergites 2-8 black with white posterior markings (Figs 1, 2). Mesoscutum entirely black, propodeum and first metasomal tergite red. Upper valve of ovipositor with weak nodus; tip of valve beyond nodus very long, 1.4 times as long as hind tarsomere 2 (Fig. 3) L. caudator sp.n.

- Ovipositor shorter, sheath $0.4-1.0$ times as long as hind tibia. Metasoma reddish brown ................................. 2.

\footnotetext{
* About 30 species of North American Lymeon with other types of colouration of metasoma were keyed before [Kasparyan, Ruíz, 2004, 2008; Kasparyan, 2013]. Recently described L. alboniger Kasparyan, 2017 has similar colouration of metasoma, but may easily be separated by its unusual (autapomorphous) colouration of middle and hind basitarsi which are white in basal half and black in apical half (in other species of Lymeon basitarsi usually darker at base or unicoloured).
} 
2. Propodeum at least basally black (Figs 7, 11; in L. transilis only transverse basal groove and front margin of proporeum are black); metapleurum reddish ............ 3 .

- Propodeum red (usually white on apophyses). Hind coxa red.

8.

3. Mesoscutum entirely black or with one white central large spot covering at least 0.5 of mesoscutum length. Propodeum with only basal transverse carina present, the apical carina absent and represented only by a pair of rather blunt conical apophyses; hind leg yellowish rufous except for white tarsomeres (1)2-4 and black tarsomere 5 (Figs 4, 9) .

- Mesoscutum with two median white or yellowish stripes

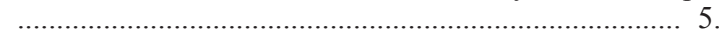

4. Mesoscutum with large median oval white spot covering at least 0.5 of mesoscutum length (Fig. 11). Frons almost polished. Clypeus granulated, its lower margin with median small brownish impression; scape black ventrally (Fig. 10). Speculum and mesosternum whitish; postscutellum white (Fig. 11). Tergite 1 of metasoma twice as long as wide posteriorly (Fig. 12), tergite 2 with white apical band; tergites 7 and 8 without white apical spot (Fig. 9). Tip of dorsal valve of ovipositor beyond the nodus distinctly depressed in apical 0.35 (Fig. 13) .... L. xalapensis sp.n.

- Mesoscutum entirely black (Fig. 6). Frons granulated. Clypeus polished, its lower margin with a pair of small brownish teeth or irregularities on lower margin; scape whitish ventrally (Fig. 5). Speculum and mesosternum black; hind leg yellowish rufous with (Fig. 4); postscutellum black (Figs 4, 7). Tergite 1 of metasoma 3.3 times as long as wide posteriorly (Fig. 7), tergite 2 without white apical band; tergites 7 and 8 with white apical spot (Fig. 4). Tip of dorsal valve of ovipositor beyond the nodus hardly depressed in apical 0.35 (Fig. 8) ........... L. scitula sp.n.

5. Front wing with two distinct transverse brownish bands. Scape black. Flagellomeres 4-10 white, black ventrally. Head predominantly white with black markings; thorax black with white spots; propodeum black, apophyses white, conical. Metasoma reddish with postpetiole, hind margin of tergite 2, and dorsum of tergite 7 white. Hind coxa entirely reddish, without white dorsal spot. Mexico

L. tinctipennis Kasparyan et Ruíz-Cancino, 2004

- Front wing hyaline, without fuscous bands. Scape ventrally reddish or whitish; hind corner of pronotum, speculum and mesosternum whitish; postscutellum white or brownish, and metapleurum (except on margins) whitish-yellow or reddish. Tergite 7 reddish (at most hind margin white). Hind coxa red, usually with dorsal white spot ............ 6 .

6. Mesopleura medially with oblique black band (from mesopleural pit to subtegular ridge). White flagellomeres brownish ventrally; scape reddish brown beneath; pedicel with dorsal white spot. Mesoscutum black, with two large median yellow stripes. Postscutellum white. Propodeum black with two large whitish spots extended from basal transverse carina through apophyses to apex; metapleurum whitish yellow. Hind tarsus with basitarsus completely reddish. Flagellomeres 1 and 2 combined about 1.3 times as long as maximum diameter of eye. Fourth tarsomere of hind leg bilobed, the distal lobe 1.6 times as long as proximal one. In the type specimen ovipositor beyond the nodus strongly compressed, 1.05 times as long as segment 2 of hind tarsus. Mexico

L. junctus (Cresson, 1873)

- Mesopleura medially without oblique black band. White flagellomeres not darkened ventrally; scape white beneath; pedicel without dorsal white spot in L. sulsus.
Postscutellum brownish. Propodeum predominantly reddish with white. Flagellomeres 1 and 2 combined about 1.6-1.7 times as long as maximum diameter of eye. The groove between metanotum and propodeum black, shallow and broad, below postscutellum with vertical wrinkles 7.

7. Pronotum on latero-posterior (vertical) margin black, except before tegula. Mesoscutum black, with two median yellow stripes. Propodeum with two sublateral white spots covering apophyses and extending to apex; rufous between apophyses. Mexico ................ L. sulsus (Cresson, 1873)

- Pronotum on hind (vertical) margin broadly white. Mesoscutum reddish with black margins and with two yellow median stripes. Propodeum reddish, white only on apophyses. Mexico ……......... L. transilis (Cresson, 1873)

8. Head completely black (except for white mandibles and palpi). Legs uniformly reddish, only fore coxa and trochanters white and last tarsal segments brownish. Metasoma completely reddish. In female mesosoma entirely red (except for small white markings); scape reddish brown; flagellum with about 4 segments white; front wing with two fuscous bands: just distad of basal vein, and subapical one. In male wings without fuscous bands, and mesosoma may be entirely black except for reddish metapleuron and propodeum. USA (Texas), Mexico, Guatemala L. imbecillis (Cresson, 1873) (=leucosoma Cameron, 1886)

- Head predominantly reddish, whitish or yellowish. The body almost completely reddish ................................ 9.

9. Propodeum with only basal transverse carina present, the apical carina absent and represented only by a pair of rather blunt conical apophyses ................................. 10.

- Propodeum with both transverse carinae. Fore wing with two or three dark transverse markings ..................... 11.

10. Fore wing with two distinct fuscous bands. Second tergite with setiferous punctures scarce and setae very short. Scape and pedicel blackish with brownish tinge ventrally; fore coxa white, hind tibia brownish with subbasal white ring; pterostigma blackish. Metasomal sternites completely brownish. Mexico

L. maculipennis Kasparyan, 2017

- Fore wing hyaline, slightly infuscate. Second tergite with dense setiferous punctures, distances between them equal to length of setae. Scape pale brownish yellow; fore coxa, fore and mid legs yellowish red; pterostigma dirty yellow. Metasomal sternites 1-4 light yellow to whitish yellow. Yellow pattern on thorax richer (including speculum, prepectus, mesosternum and metapleuron). Honduras .

L. yanegai Kasparyan, 2004

11. Propodeum with two transverse carinae without tubercles. Clypeus not projecting downwards. Front wing slightly infuscated on basal vein, on areolet and at apex. Petiole yellow at base. Mexico

L. mexicanus (Cameron, 1886)

- Propodeum with strong crests at apical transverse carina. Clypeus strongly projecting downwards. Front wing with a median and subapical slightly infuscate bands. USA (New Mexico) …………….... L. nasutus (Pratt, 1945)

Acknowledgments. I am cordially grateful to M. LópezOrtega (Xalapa, Mexico) and Andrey Khalaim (ZIN) for new materials on Cryptini, and also to Yulia Astafurova (ZIN) and Andrey Khalaim for their kind help with the preparation of photographs. The work was supported by the Russian Foundation for Basic Research (grant no. 19-04-00027) and performed in the framework of the Russian State Research Project no. AAAA-A19-1190206900101-6. 


\section{References}

Kasparyan D.R. 2004. Four new species of Lymeon Förster and Latosculum Townes (Hymenoptera: Ichneumonidae, Cryptinae) from Honduras and Mexico // Proceedings of the Russian Entomological Society (St. Petersburg). Vol.75. No.1. P.27-34

Kasparyan D.R. 2013. A contribution to the knowledge of ichneumon flies of the tribe Cryptini (Hymenoptera: Ichneumonidae: Cryptinae) from Mexico // Zoosystematica Rossica. Vol.22. No.1. P.93-106. https://doi.org/10.31610/zsr/2013.22.1.93.

Kasparyan D.R. 2017. Two new species of the genus Lymeon (Hymenoptera: Ichneumonidae: Cryptinae: Cryptini) from Mexico // Zoosystematica Rossica. Vol.26. No.2. P.276-281. https:/ /doi.org/10.31610/zsr/2017.26.2.276.

Kasparyan D.R., Ruíz-Cancino E. 2004. Review of North American species of the genus Lymeon Foerster, 1869 (Hymenoptera: Ichneumonidae: Cryptini) // Zoosystematica Rossica. Vol.13. No.1. P.53-79.
Kasparyan D.R., Ruíz-Cancino E. 2008a. Cryptini de México (Hymenoptera: Ichneumonidae: Cryptinae). Parte II. Serie Avispas parasíticas de plagas y otros insectos. Cd. Victoria, Tamaulipas, Mexico. UAT. 373 pp.

Kasparyan D.R., Ruíz-Cancino E. 2008b. A new species of Lymeon Foerster from Mexico (Hymenoptera, Ichneumonidae: Cryptini) // Zoosystematica Rossica. Vol.17. No.1. P.93-94.

Scherrer M.V., Aguiar A.P. 2012. A review of Debilos Townes (Hymenoptera, Ichneumonidae, Cryptinae) with description of twenty-seven new species // Zootaxa. Vol.3469. No.1. P.1-76. https://doi.org/10.11646/zootaxa.3469.1.1.

Townes H.K. 1970. The genera of Ichneumonidae, Part 2 // Memoirs of the American Entomological Institute. No.12(1969). P.15-37. Townes H.K., Townes M. 1962. Ichneumon-flies of America North of Mexico: 3. Subfamily Gelinae, tribe Mesostenini // Bulletin of the United States National Museum. Vol.216. No.3. P.1-602. Yu D.S.K., van Achterberg C., Horstmann K. 2016. Taxapad 2016 , Ichneumonoidea 2015. Database on flash-drive. Nepean, Ontario, Canada. 